\title{
Phytotoxicity of Major Constituents of the Volatile Oil from Leaves of Artemisia scoparia Waldst. \& Kit.
}

\author{
Harminder Pal Singh ${ }^{\mathrm{a}}$, Shalinder Kaur ${ }^{\mathrm{b}}$, Sunil Mittal ${ }^{\mathrm{a}}$, Daizy R. Batish ${ }^{\mathrm{b}, *}$, \\ and Ravinder K. Kohli ${ }^{\mathrm{a}, \mathrm{b}}$ \\ a Centre for Environment and Vocational Studies, Department of Botany, Panjab University, \\ Chandigarh 160 014, India \\ b Department of Botany, Panjab University, Chandigarh 160 014, India. \\ E-mail: daizybatish@yahoo.com \\ * Author for correspondence and reprint requests \\ Z. Naturforsch. 63c, 663-666 (2008); received March 6/April 7, 2008
}

The phytotoxicity of the three major monoterpene constituents of the essential oil from leaves of Artemisia scoparia Waldst. \& Kit. (redstem wormwood) was investigated. GC/GCMS analysis revealed that the essential oil (yield $0.84 \%$ ) is a complex mixture containing 19 monoterpenes, 7 sesquiterpenes and 15 other compounds - aliphatic alcohols, ketones, aromatic hydrocarbons and esters. The three major monoterpenes were $\beta$-myrcene $(30.2 \%)$, $p$-cymene $(12.8 \%)$ and $d l$-limonene $(12.4 \%)$. The essential oil and the three monoterpenes exhibited phytotoxicity and reduced germination, seedling growth, chlorophyll content and percent respiration of Avena sativa and Triticum aestivum in a dose-response manner. The inhibitory effect of monoterpenes was comparatively smaller than of the crude essential oil and $\beta$-myrcene was most toxic followed by $p$-cymene, whereas limonene was least toxic. The study suggests that $A$. scoparia oil and $\beta$-myrcene can be explored for phytotoxicity against weeds.

Key words: Artemisia scoparia, $\beta$-Myrcene, Phytotoxicity

\section{Introduction}

Artemisia (commonly wormwoods; family Asteraceae) is a diverse genus with over 200 species of perennial herbs and shrubs distributed in various parts of the world (Anonymous, 1993). It is known for the presence of volatile oils that are extensively used in medicines and as antimicrobial agent (Anonymous, 1993). Additionally, a few of the Artemisia species inhibit the germination and growth of other plants through their volatile oils/ terpenes and are responsible for the characteristic patterning of vegetation. These include $A$. californica (Muller et al., 1964), A. tridentata (Weaver and Klarich, 1977), A. princeps var. orientalis (Yun et al., 1993), and A. vulgaris (Barney et al., 2005). However, not all species of Artemisia have been explored for their allelopathic potential, though they contain essential oil and possess a characteristic aroma. Artemisia scoparia (redstem wormwood) is one such species that grows extensively in India, particularly in the lower parts of western Himalayas and Gangetic plains, and forms monospecific strands. It has a dark reddish stem with numerous small leaves and grows up to $\sim 1.5 \mathrm{~m}$ in height. All the above ground parts of $A$. scoparia are aromatic and contain volatile essential oil that possesses medicinal, antifungal and antimicrobial properties (Anonymous, 1993). However, very little is known about the role of the essential oil in imparting allelopathic nature to the plant and thus regulating the vegetation in its vicinity. In the present study, the allelopathic/phytotoxic properties of the volatile essential oil from above ground parts of A. scoparia was investigated to identify the bioactive constituents of its oil. To explore the phytotoxicity of $A$. scoparia essential oil we selected 2 plants - Avena sativa (oat) and Triticum aestivum (wheat).

\section{Materials and Methods}

\section{Collection of plant material and extraction of the essential oil}

Green leaves were collected from nearly 5-weekold plants of redstem wormwood (Artemisia scoparia Waldst. \& Kit.) growing in wild strands around the campus of Panjab University, Chandigarh, India in May 2007. They were used for oil extraction through steam-distillation in a Cleven- 
ger's apparatus. Green leaves ( $200 \mathrm{~g})$ were mixed with $750 \mathrm{~mL}$ of distilled water in a $2 \mathrm{~L}$ round bottom flask fitted with a condenser and heated for $3 \mathrm{~h}$. The oil was collected from the nozzle of the apparatus and dried over sodium sulfate and stored at $4{ }^{\circ} \mathrm{C}$ till further use.

\section{$G C / G C-M S$ analysis of the essential oil}

GC was done on a Shimadzu gas chromatograph (model GC-14B) fitted with a FID (flame ionization detector), Supelco wax column $(60 \mathrm{~m} \times$ $0.25 \mathrm{~mm}$ i. d., film thickness $0.25 \mu \mathrm{m}$ ) and using $\mathrm{N}_{2}$ as carrier gas. The oven temperature was initially held isothermally at $40^{\circ} \mathrm{C}$ for $4 \mathrm{~min}$, then increased to $220{ }^{\circ} \mathrm{C}$ at the rate of $4{ }^{\circ} \mathrm{C} / \mathrm{min}$ and finally held for $5 \mathrm{~min}$. Relative amounts of different chemical components were determined by computer-based peak area normalization without any correction factor.

GC-MS was performed on a Perkin-Elmer mass spectrophotometer (Model Q Mass 910) equipped with a fused silica (BP 21) capillary column (30 m $\times 0.25 \mathrm{~mm}$ i. d., film thickness $0.25 \mu \mathrm{m}$ ) and using $\mathrm{He}$ as carrier gas. The oven temperature was initially held isothermally at $40^{\circ} \mathrm{C}$ for $7 \mathrm{~min}$, then increased to $190{ }^{\circ} \mathrm{C}$ at the rate of $5{ }^{\circ} \mathrm{C} / \mathrm{min}$ and finally held for $20 \mathrm{~min}$. Injector and detector temperature were $230{ }^{\circ} \mathrm{C}$ and $250{ }^{\circ} \mathrm{C}$, respectively.

The constituents were identified based on computer matching of mass spectra using the library search system HP-5872 (Hewlett-Packard), consulting data bases (Wiley 275 and NBS 75K), libraries, and NIST 98 (McLafferty, 1988; Stein, 1990), and compilation by Adams (1995).

\section{Phytotoxicity of the essential oil and its major constituents}

To assess the role of the essential oil in regulating the vegetation in the vicinity of $A$. scoparia, the phytotoxicity of the essential oil and its major monoterpenes ( $\beta$-myrcene, $d l$-limonene and $p$-cymene) was studied against Avena sativa (oat) and Triticum aestivum (wheat). 20 Seeds (pre-imbibed for $16 \mathrm{~h}$ in distilled water) of each test plant were placed in $15 \mathrm{~cm}$ diameter Petri dishes each lined with a single layer Whatman no. 1 filter circle moistened with $7 \mathrm{ml}$ of Artemisia essential oil or either of the three monoterpenes or distilled water (as control). Three concentrations $-0.14,0.35$ and $0.70 \mathrm{mg} / \mathrm{mL}$ - of the essential oil and the major monoterpenes were used. In total, there were 13 treatments including control. There were five Petri dish replicates for each treatment including control. We used the oil and monoterpenes as $\mathrm{mg} / \mathrm{mL}$ rather than mM, since the molecular weight of the essential oil was unknown. All the Petri dishes were maintained in a growth chamber set at $(23 \pm 2) /(18 \pm 2){ }^{\circ} \mathrm{C}$ day/night temperature, a $14 \mathrm{~h}$ photoperiod (06.00 AM to $08.00 \mathrm{PM})$ of $\sim 260 \mu \mathrm{mol} \mathrm{m}^{-2} \mathrm{~s}^{-1}$ photon flux density and a relative humidity of $\sim 75 \%$. After $7 \mathrm{~d}$, percent germination and seedling length were measured. The leaves were removed and analyzed for chlorophyll content and respiratory activity. Chlorophyll was extracted with dimethyl sulfoxide and analyzed spectrophotometrically (Hiscox and Israelstam, 1979) and calculated using the equation of Arnon (1949). The respiratory activity was determined using 2,3,5-triphenyl tetrazolium chloride according to Steponkus and Lanphear (1967).

The observed data were analyzed by one-way ANOVA and their significance in response to the essential oil or the major monoterpenes was determined over control by post hoc Dunnett's test.

\section{Results and Discussion}

GC and GC-MS analyses revealed that the essential oil (yield $0.84 \%$ ) from Artemisia scoparia leaves is a complex mixture of 41 constituents (19 monoterpenes, 7 sesquiterpenes and 15 other compounds - aliphatic alcohols, ketones, aromatic hydrocarbons and esters) that are isolated between 4 to 38.4 minutes (data not presented). Among them, the major monoterpenes were $\beta$-myrcene $(30.2 \%), \quad p$-cymene $(12.8 \%)$ and $d l$-limonene $(12.4 \%)$ (Table I). This is in sharp contrast to earlier reports showing that $A$. scoparia oil is rich in camphor, 1,8-cineole and $\beta$-caryophyllene (Cha et al., 2005), in $\alpha$ - and $\beta$-thujone (Farzaneh et al., 2006), and in capillene (Demirci et al., 2005). Studies in the past have demonstrated the antimicrobial and fungicidal activity of $A$. scoparia essential oil (Yun et al., 1993; Cha et al., 2005; Farzaneh et

Table I. The three major monoterpene components of the essential oil from leaves of Artemisia scoparia as revealed by GC-MS analysis.

\begin{tabular}{lccc}
\hline Component & $\begin{array}{c}\text { Retention } \\
\text { time [min] }\end{array}$ & $\begin{array}{c}\text { Relative } \\
\text { area }(\%)\end{array}$ & Kovats index \\
\hline$\beta$-Myrcene & 4.16 & 30.2 & 1161 \\
$d l$-Limonene & 4.82 & 12.4 & 1201 \\
$p$-Cymene & 6.44 & 12.8 & 1269 \\
\hline
\end{tabular}


al., 2006); however, nothing has been done to explore the phytotoxicity of the oil. It is imperative in view of the increasing reports that volatile oils have a good potential for the use as weed management agent under organic farming (Singh et al., 2003; Batish et al., 2004, 2007). We therefore analyzed the phytoinhibitory activity of $A$. scoparia essential oil and its three major monoterpenes ( $\beta$-myrcene, $p$-cymene and $d l$-limonene) against T. aestivum and $A$. sativa.

The essential oil from leaves of $A$. scoparia significantly (at $p<0.01$ ) inhibited the germination, early growth, chlorophyll content and respiration of both the test plants (Table II). A parallel reduction in germination was observed in response to $\beta$-myrcene and $p$-cymene (except on wheat), whereas there was no effect for $d l$-limonene. Likewise, there was a significant (at $p<0.01$ ) reduction in seedling length, chlorophyll content and percent respiration in both the test plants in response to all the three monoterpenes, though the effect was variable (Table II). In general, the crude essential oil was more phytotoxic than its major components $\beta$-myrcene, $p$-cymene and $d l$-limonene, and the inhibitory effect was more on $A$. sativa than on T. aestivum. Among the monoterpenes, $\beta$-myrcene was most potent followed by $p$ cymene and $d l$-limonene (Table II). Earlier studies have shown that volatile essential oil from aromatic plants (herbs, shrubs and trees) reduces the germination and growth of other plants (Muller et al., 1964; Batish et al., 2006). The growth retardatory effect of essential oil of $A$. scoparia and its major monoterpene components parallels the observed scattered vegetation around A. scoparia. Further, the study bears significance in view that essential oils are being explored for their weed/ pest suppressing properties (Singh et al., 2003). The reduction in chlorophyll content in response to A. scoparia essential oil and its major monoterpenes is in agreement with earlier reports indicating a negative effect of essential oils and monoterpenes (Abrahim et al., 2000; Singh et al., 2002a, b, 2005; Batish et al., 2004). Earlier, Weaver and Klarich (1977) have documented that volatile monoterpenes from $A$. tridentata reduce the respiration in young and juvenile wheat plants.

The present study concludes that $A$. scoparia essential oil and its three major monoterpenes $(\beta$ myrcene, $p$-cymene and $d l$-limonene) reduce germination, growth, chlorophyll content and respiration of target species - T. aestivum and A. sativa.

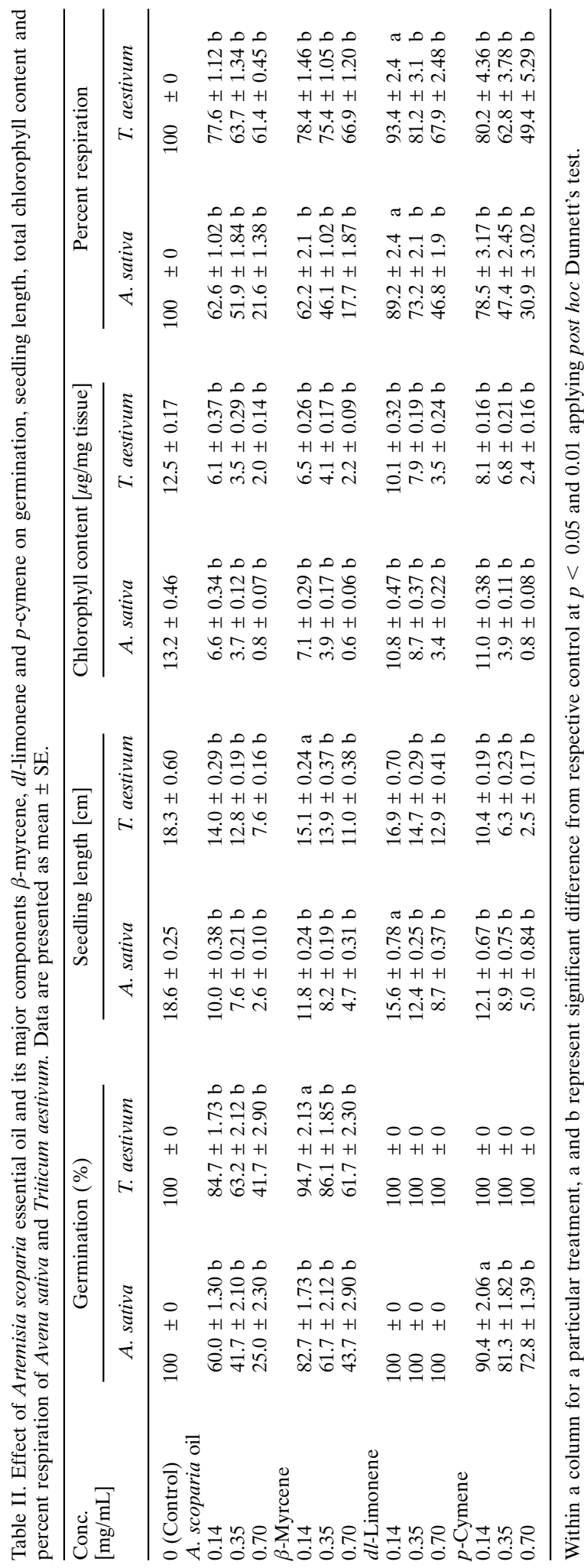


However, the inhibitory effect of the monoterpenes was comparatively lesser than that of the crude essential oil, and among them $\beta$-myrcene was most toxic followed by $p$-cymene, whereas limonene was least toxic. The phytotoxicity of the oil and $\beta$-myrcene qualify them to be explored for possible phytotoxicity against a wide range of weeds.

\section{Acknowledgements}

Shalinder Kaur and Sunil Mittal are thankful to Department of Science and Technology and University Grants Commission (New Delhi, India) for financial support.
Abrahim D., Braguini W. L., Kelmer-Bracht A. M., and Ishii-Iwamoto E. L. (2000), Effects of four monoterpenes on germination, primary root growth and mitochondrial respiration of maize. J. Chem. Ecol. 26, $611-624$

Adams R. P. (1995), Identification of Essential Oils Components by Gas Chromatography and Mass Spectrometry. Allured Publishers Corp., Carol Stream, Illinois.

Anonymous (1993), Artemisia Linn. In: The Wealth of India - Raw Materials, Vol. III ( $\mathrm{Ca}-\mathrm{Ci})$, Revised Series (Phondke G. P., ed.). Council of Scientific and Industrial Research, New Delhi, India, pp. 434-442.

Arnon D. I. (1949), Copper enzymes in isolated chloroplasts: Polyphenylperoxidase in Beta vulgaris. Plant Physiol. 24, 1-15.

Barney J. N., Hay A. G., and Weston L. A. (2005), Isolation and characterization of volatiles from mugwort. J. Chem. Ecol. 31, 247-265.

Batish D. R., Setia N., Singh H. P., and Kohli R. K. (2004), Phytotoxicity of lemon-scented eucalypt oil and its potential use as a bioherbicide. Crop Prot. 23, 1209-1214.

Batish D. R., Singh H. P., Setia N., Kaur S., and Kohli R. K. (2006), Chemical composition and phytotoxicity of volatile essential oils from intact and fallen leaves of Eucalyptus citriodora. Z. Naturforsch. 61c, 465471.

Batish D. R., Singh H. P., Setia N., Kohli R. K., and Yadav S. S. (2007), Alternative control of littleseed canary grass using eucalypt oil. Agron. Sustain. Dev. 27, $171-177$.

Cha J. D., Jeong M. R., Jeong S. I., Moon S. E., Kim J. Y., Kil B. S., and Song Y. H. (2005), Chemical composition and antimicrobial activity of the essential oils of Artemisia scoparia and A. capillaris. Planta Med. 71, 186-190.

Demirci B., Demirci F., and Başer K.H. C. (2005), Headspace-SPME and hydrodistillation of two fragrant Artemisia sp. Flav. Fragr. J. 20, 395-398.
Farzaneh M., Ahmadzadeh M., Hadian J., and Tehrani A. S. (2006), Chemical composition and antifungal activity of the essential oils of three species of Artemisia on some soil-borne phytopathogens. Comm. Agric. Appl. Biol. Sci. 71, 1327-1333.

Hiscox J. D. and Israelstam G. F. (1979), A method for extraction of chlorophyll from leaf tissue without maceration. Can. J. Bot. 57, 1332-1334.

McLafferty F. W. (1988), Registry of Mass Spectral Data, 5 th ed. John Wiley and Sons, New York.

Muller C. H., Muller W. H., and Haines B. L. (1964), Volatile growth inhibitors produced by aromatic shrubs. Science 143, 471-473.

Singh H. P., Batish D. R., and Kohli R. K. (2002a), Allelopathic effects of two volatile monoterpenes against bill-goat weed (Ageratum conyzoides L.). Crop Prot. 21, 347-350.

Singh H. P., Batish D. R., Kaur S., Ramezani H., and Kohli R. K. (2002b), Comparative phytotoxicity of four monoterpenes against Cassia occidentalis. Ann. Appl. Biol. 141, 111-116.

Singh H. P., Batish D. R., and Kohli R. K. (2003), Allelopathic interactions and allelochemicals: new possibilities for sustainable weed management. Crit. Rev. Plant Sci. 22, 239-311.

Singh H. P., Batish D. R., Setia N., and Kohli R. K. (2005), Herbicidal activity of volatile oils from Eucalyptus citriodora against Parthenium hysterophorus. Ann. Appl. Biol. 146, 89-94.

Stein S. E. (1990), Mass Spectral Database and Software, Ver. 3.02. National Institute of Standards and Technology (NIST), Gaithersburg, Maryland, USA.

Steponkus P. L. and Lanphear F. O. (1967), Refinement of the triphenyl tetrazolium chloride method of determining cold injury. Plant Physiol. 42, 1423-1426.

Weaver T. and Klarich D. (1977), Allelopathic effects of volatile substances from Artemisia tridentata Nutt. Am. Midl. Nat. 97, 508-512.

Yun K. W., Kil B. S., and Han D. M. (1993), Phytotoxic and antimicrobial activity of volatile constituents of Artemisia princeps var. orientalis. J. Chem. Ecol. 19, 2757-2766. 